\title{
Highly Efficient Abnormal NHC Ruthenium Catalyst for Oppenauer- type Oxidation and Transfer Hydrogenation Reactions
}

\author{
Lorenz Pardatscher," Benjamin J. Hofmann,, Pauline J. Fischer," Sebastian M. Hölzl,, Robert M. Reich," \\ Fritz E. Kühn, ${ }^{* *}$ Walter Baratta ${ }^{*+}$ \\ \# Technische Universität München, Department of Chemistry, Molecular Catalysis \& Catalysis Research Center, \\ Lichtenbergstraße 4, D-85747 Garching bei München, Germany, E-mail: fritz.kuehn@ch.tum.de. \\ + Università di Udine, Dipartimento DI4A, Via Cotonificio 108, 33100 Udine, Italy, E-mail: walter.baratta@uniud.it. \\ KEYWORDS N-heterocyclic carbenes • alcohols $\bullet$ carbonyl compounds $\bullet$ Ruthenium • Oppenauer-type oxidation • transfer \\ hydrogenation • smart ligands.
}

\section{Table of Contents:}

General remarks 3

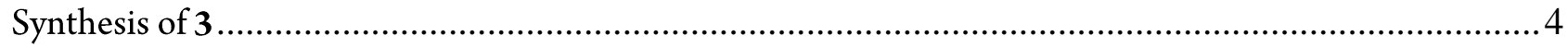

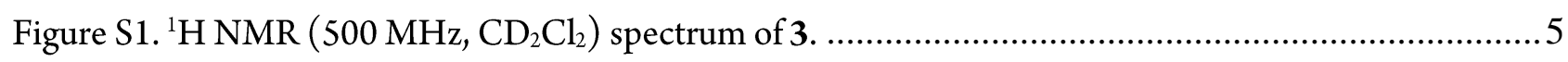

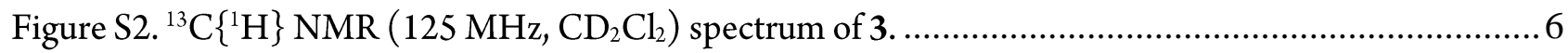

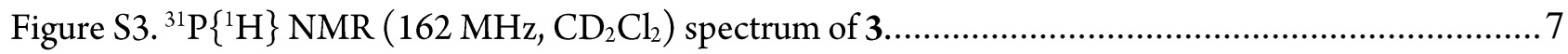

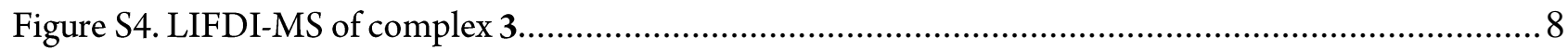

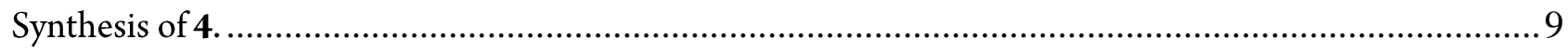

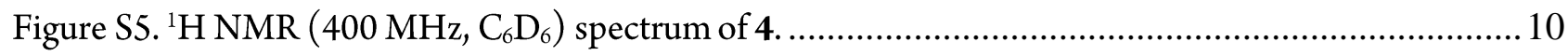

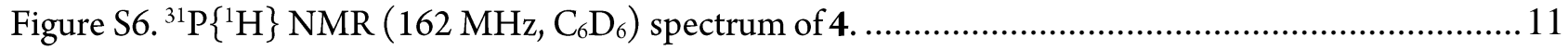

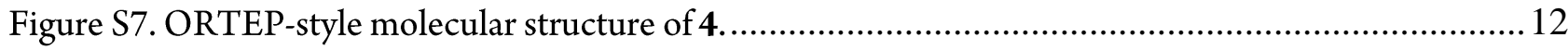

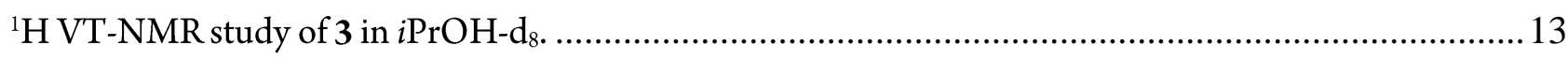

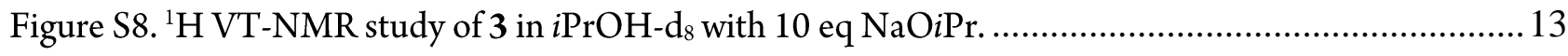

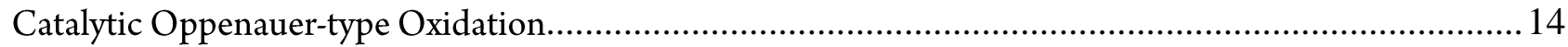




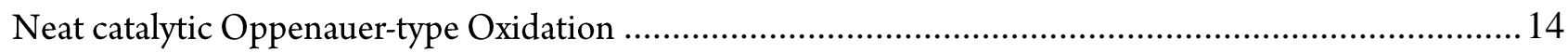

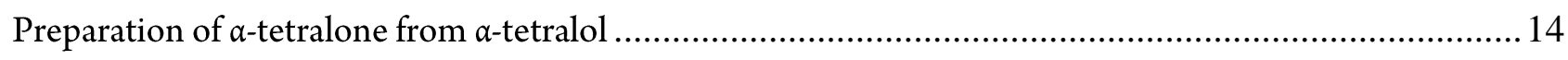

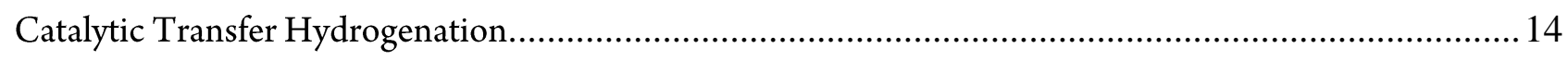

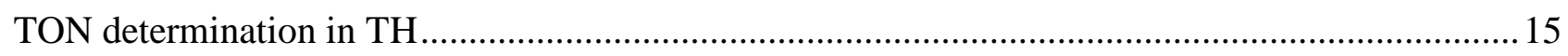

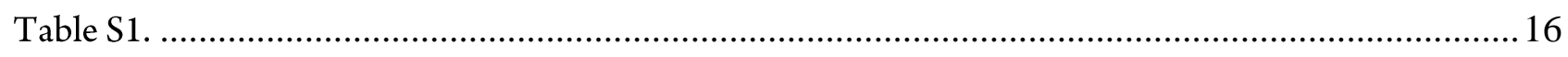

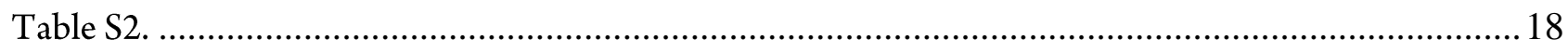

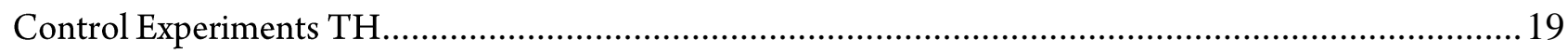

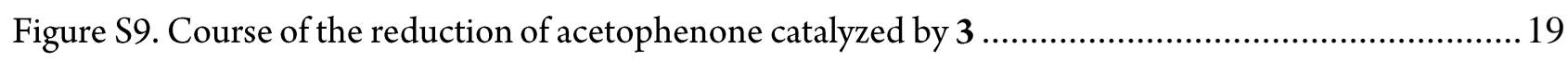

Single crystal X-Ray structure determination. General data........................................................ 20

Single crystal X-ray structure determination. Detailed crystallographic data. ........................................2 21

5.3.7.6 Crystallographic Data of Complex 3 CCDC: 1936771 ..................................................... 21

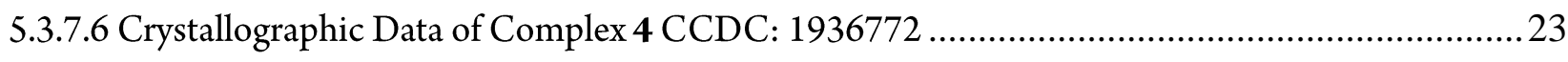

Single crystal X-ray structure determination. References. ......................................................... 25

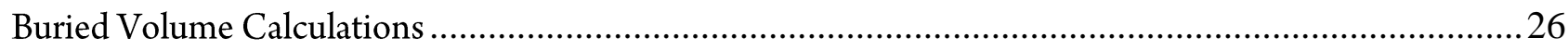

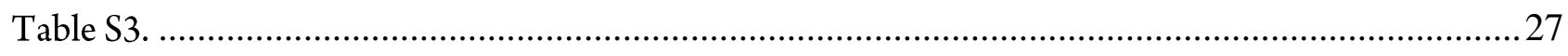

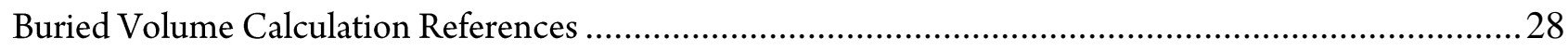




\section{General remarks}

Unless otherwise specified, all reactions were performed under oxygen free, dry conditions in an argon atmosphere using standard Schlenk conditions and glovebox techniques. The solvents used were purified, degassed and dried according to standard purification techniques or obtained from a M. Braun SPS purification system. If not noted differently, all further chemicals were purchased from commercial sources and used as received. NMR spectra were acquired on a Bruker Avance Ultrashield $400 \mathrm{MHz}$ and a Bruker DPX $400 \mathrm{MHz}$ spectrometer. All ${ }^{1} \mathrm{H}$ and ${ }^{13} \mathrm{C}$ chemical shifts are reported in parts per million (ppm) relative to TMS, with the residual solvent peak serving as internal reference. ${ }^{31} \mathrm{P}$ NMR spectra are referenced to $85 \%$ $\mathrm{H}_{3} \mathrm{PO}_{4}$ as external standard. Single crystals were measured in the SC-XRD laboratory of the Catalysis Research Center at Technische Universität München. LIFDI mass spectrometry was detected with a Waters LCT. The special ionization cell was obtained from Linden CMS GmbH, Leeste, Germany. GC analysis was done with an Agilent Technologies 7890B GC system using an Agilent VF-200ms column $(30 \mathrm{~m} \times 250 \mu \mathrm{m} \times 0.25 \mu \mathrm{m})$. CHN analyses were carried out in the microanalytical laboratory at Technische Universität München. 


\section{Synthesis of 3}

1) Method from $\left.\mathrm{Ru}(\mathrm{OAc})_{2}\left(\mathrm{PPh}_{3}\right)_{2}\right)$

$\mathrm{Ru}(\mathrm{OAc})_{2}\left(\mathrm{PPh}_{3}\right)_{2}(221 \mathrm{mg}, 0.30 \mathrm{mmol}, 1.0 \mathrm{eq}), \mathbf{P C}-\mathrm{HBr}(300 \mathrm{mg}, 0.63 \mathrm{mmol}, 2.1 \mathrm{eq})$ and anhydrous $\mathrm{NaOAc}$ (244 mg, $2.98 \mathrm{mmol}, 10.0 \mathrm{eq}$ ) are dissolved in $10 \mathrm{~mL}$ of dry and degassed THF and stirred for $6 \mathrm{~h}$ at $60^{\circ} \mathrm{C}$. The resulting precipitate is isolated via a whatman-filtration, washed with $2 \mathrm{~mL}$ of THF and dissolved in $5 \mathrm{~mL}$ of dichloromethane. The yellow solution is filtered off, the solvent is removed under reduced pressure and the resulting solid is washed with $n$-hexane. The product 3 is obtained as a yellow powder. Yield: $260 \mathrm{mg}(85 \%)$.

Elemental analysis calcd (\%) for $\mathrm{C}_{54} \mathrm{H}_{57} \mathrm{BrN}_{4} \mathrm{O}_{2} \mathrm{P}_{2} \mathrm{Ru}$ : C, 62.55; H, 5.54; N, 5.40. Found: C, 62.11; H, 5.68;

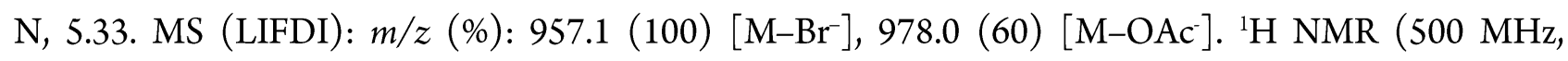
$\left.\mathrm{CD}_{2} \mathrm{Cl}_{2}, \mathrm{RT}\right): \delta 8.72\left(\mathrm{~d},{ }^{4} J=1.7 \mathrm{~Hz}, 2 \mathrm{H}, \mathrm{NCHN}\right), 7.75\left(\mathrm{~m}, 4 \mathrm{H}, \mathrm{Ph}_{\text {ortho }}\right), 7.38\left(\mathrm{t},{ }^{3} J=7.5 \mathrm{~Hz}, 2 \mathrm{H}, \mathrm{Ph}_{\text {para }}\right)$, 7.30-7.21 (m, 6H, $\mathrm{Ph}_{\text {meta+para }}$ ), $7.15\left(\mathrm{t},{ }^{3} \mathrm{~J}=7.5 \mathrm{~Hz}, 4 \mathrm{H}, \mathrm{Ph}_{\text {meta }}\right.$ ), 7.00 (s, 2H, $\operatorname{Ar}_{\text {Mes }}$ ), 6.92 (s, 2H, $\left.\operatorname{Ar}_{\text {Mes }}\right), 6.54$ $\left(\mathrm{d},{ }^{4} \mathrm{~J}=1.7 \mathrm{~Hz}, 2 \mathrm{H}, \mathrm{NCCHN}\right), 6.50\left(\mathrm{~m}, 4 \mathrm{H}, \mathrm{Ph}_{\text {ortho }}\right.$ ), 4.71-4.57 (m, 2H, $\left.\mathrm{NCH}_{2} \mathrm{CH}_{2} \mathrm{P}\right), 4.21-4.11(\mathrm{~m}, 2 \mathrm{H}$, $\mathrm{NCH}_{2} \mathrm{CH}_{2} \mathrm{P}$ ), 2.31 (s, 6H, MesMe para ), 2.10 (s, 6H, MesMe ortho), 1.98-1.88 (m, 2H, $\mathrm{NCH}_{2} \mathrm{CH}_{2} \mathrm{P}$ ) 1.80 (s, 9H, OAcMe, MesMe ortho), 1.69-1.59 (m, 2H, $\left.\mathrm{NCH}_{2} \mathrm{CH}_{2} \mathrm{P}\right) .{ }^{13} \mathrm{C}\left\{{ }^{1} \mathrm{H}\right\}$ NMR (125 MHz, $\mathrm{CD}_{2} \mathrm{Cl}_{2}, \mathrm{RT}$ ): $\delta$ $184.2(\mathrm{~s}, \mathrm{OAc}), 165.3\left(\mathrm{t}, J_{\mathrm{CP}}=12.4 \mathrm{~Hz}, \mathrm{NCCHN}\right), 140.3\left(\mathrm{~s}, \mathrm{Mes}_{\text {para }}\right), 138.5$ (dd, $J_{\mathrm{CP}}=17.5 \mathrm{~Hz}, J_{\mathrm{CP}}=20.1$ $\mathrm{Hz}, \mathrm{Ph}_{\mathrm{q}}$ ), $137.9\left(\mathrm{dd}, J_{\mathrm{CP}}=22.2 \mathrm{~Hz}, J_{\mathrm{CP}}=25.3 \mathrm{~Hz}, \mathrm{Ph}_{\mathrm{q}}\right.$ ), $135.1(\mathrm{~s}, \mathrm{NCN}), 134.6$ (s, Mes ortho $), 134.3$ (s, $\mathrm{Mes}_{\text {ortho }}$ ), 133.9 (t, ${ }^{2} J_{\mathrm{CP}}=4.7 \mathrm{~Hz}, \mathrm{Ph}_{\text {ortho }}$ ), 132.9 (s, $\mathrm{Mes}_{\mathrm{q}}$ ), 132.2 (s, br, Ph ortho $), 130.1\left(\mathrm{~s}, \mathrm{Ph}_{\text {para }}\right), 129.9$ (s,Ph Para $), 129.8$ (s, $\left.\mathrm{Mes}_{\text {meta }}\right), 129.8\left(\mathrm{~s}, \mathrm{Mes}_{\text {meta }}\right), 128.4\left(\mathrm{t},{ }^{3} J_{\mathrm{CP}}=4.3 \mathrm{~Hz}, \mathrm{Ph}_{\text {meta }}\right), 128.3\left(\mathrm{t},{ }^{3} J_{\mathrm{CP}}=4.5 \mathrm{~Hz}\right.$, $\mathrm{Ph}_{\text {meta }}$ ), 127.4 (s, NCCHN), $45.8\left(\mathrm{~s}, \mathrm{NCH}_{2} \mathrm{CH}_{2} \mathrm{P}\right.$ ), 26.1 (dd, ${ }^{1} J_{\mathrm{CP}}=13.7 \mathrm{~Hz},{ }^{1} J_{\mathrm{CP}}=16.0 \mathrm{~Hz}, \mathrm{NCH}_{2} \mathrm{CH}_{2} \mathrm{P}$ ), 25.3 (s, OAc), 21.3 (s, MesMe $\mathrm{e}_{\text {para }}$ ), 17.8 (s, MesMe ${ }_{\text {ortho }}$ ), 17.6 (s, MesMe ortho $) .{ }^{31} \mathrm{P}\left\{{ }^{1} \mathrm{H}\right\} \mathrm{NMR}(162 \mathrm{MHz}$, $\left.\mathrm{CD}_{2} \mathrm{Cl}_{2}, \mathrm{RT}\right): \delta 56.4(\mathrm{~s})$.

\section{2) Method from 2}

$2(270 \mathrm{mg}, 0.30 \mathrm{mmol}, 1.0 \mathrm{eq}), \mathbf{P C}-\mathbf{H B r}(158 \mathrm{mg}, 0.33 \mathrm{mmol}, 1.1 \mathrm{eq})$ and anhydrous $\mathrm{NaOAc}(123 \mathrm{mg}$, $1.50 \mathrm{mmol}, 5.0 \mathrm{eq}$ ) are dissolved in $10 \mathrm{~mL}$ of dry and degassed THF and stirred for $3 \mathrm{~h}$ at $60{ }^{\circ} \mathrm{C}$. The resulting precipitate is isolated via a whatman-filtration, washed with $2 \mathrm{~mL}$ of THF and dissolved in $5 \mathrm{~mL}$ of dichloromethane. The yellow solution is filtered off, the solvent is removed under reduced pressure and the resulting solid is washed with $n$-hexane. The product 3 is obtained as a yellow powder. Yield: $280 \mathrm{mg}$ (90\%). 


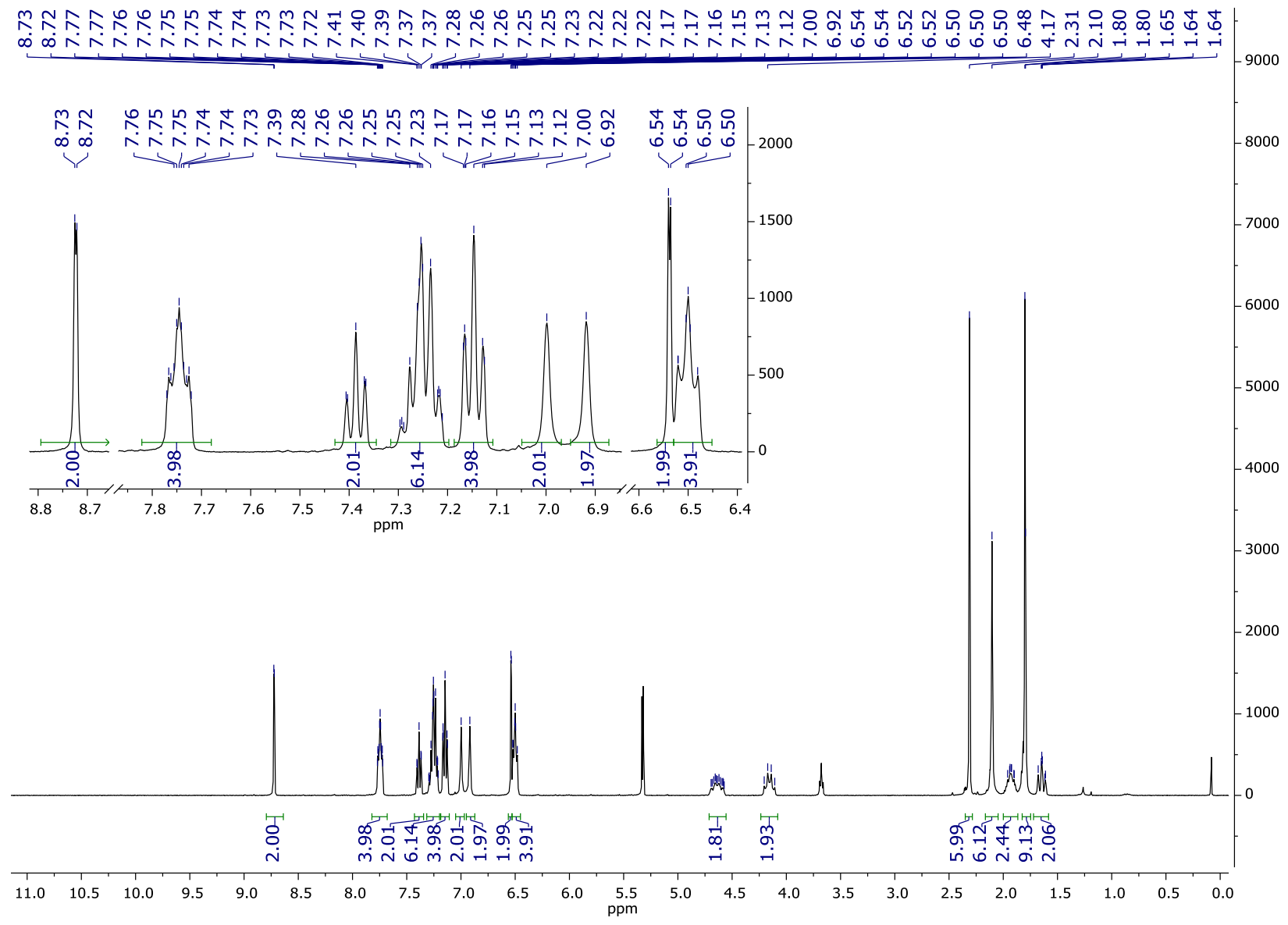

Figure S1. ${ }^{1} \mathrm{H}$ NMR ( $\left.500 \mathrm{MHz}, \mathrm{CD}_{2} \mathrm{Cl}_{2}\right)$ spectrum of 3. 


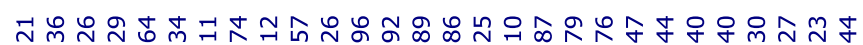

衣

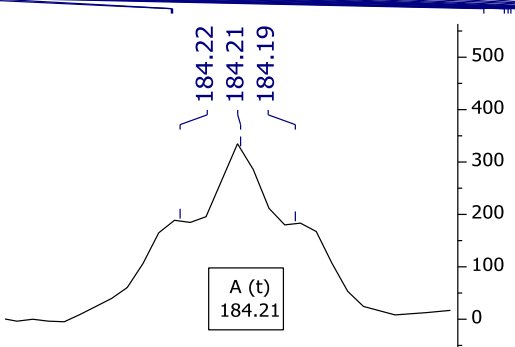

$\begin{array}{llllll}184.26 & 184.24 & 184.22 & 184.20 & 184.18 & 184.16\end{array}$

$\mathrm{ppm}$

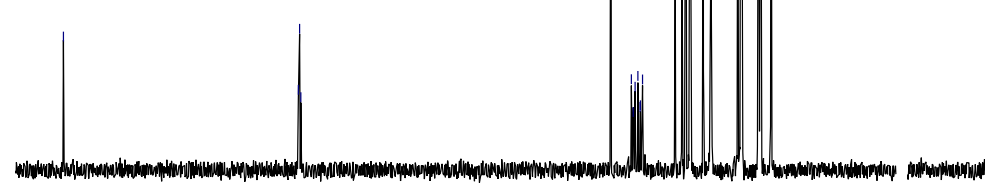

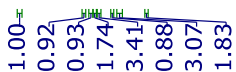

$\begin{array}{lllllllllllll}185 & 180 & 175 & 170 & 165 & 160 & 155 & 150 & 145 & 140 & 135 & 130 & \begin{array}{l}125 \\ \mathrm{ppm}\end{array}\end{array}$

Figure S2. ${ }^{13} \mathrm{C}\left\{{ }^{1} \mathrm{H}\right\}$ NMR $\left(125 \mathrm{MHz}, \mathrm{CD}_{2} \mathrm{Cl}_{2}\right)$ spectrum of 3. 12060

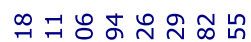

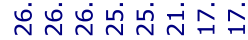

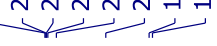

$-2400$ 


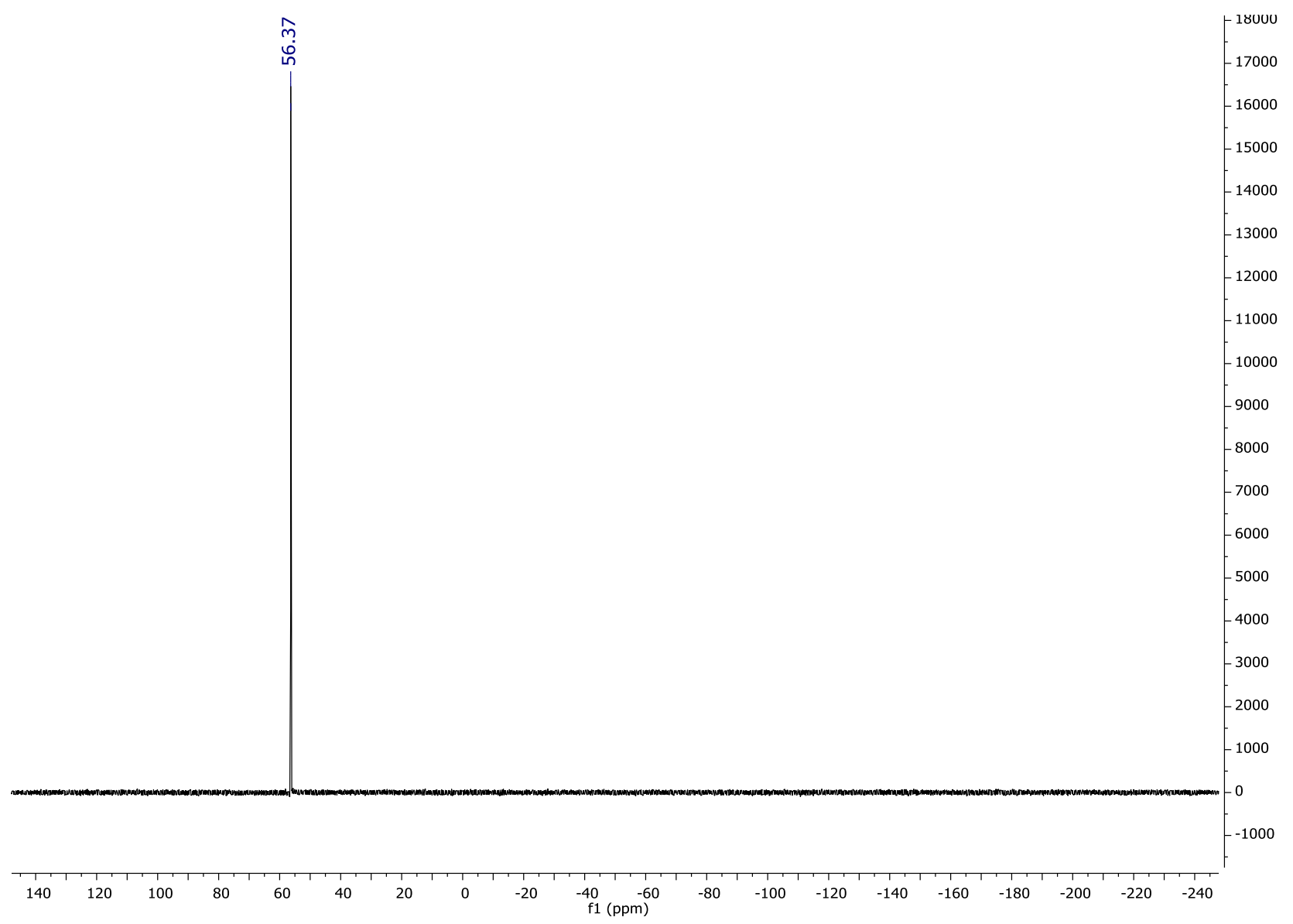

Figure S3. ${ }^{31} \mathrm{P}\left\{{ }^{1} \mathrm{H}\right\} \mathrm{NMR}\left(162 \mathrm{MHz}, \mathrm{CD}_{2} \mathrm{Cl}_{2}\right)$ spectrum of 3. 


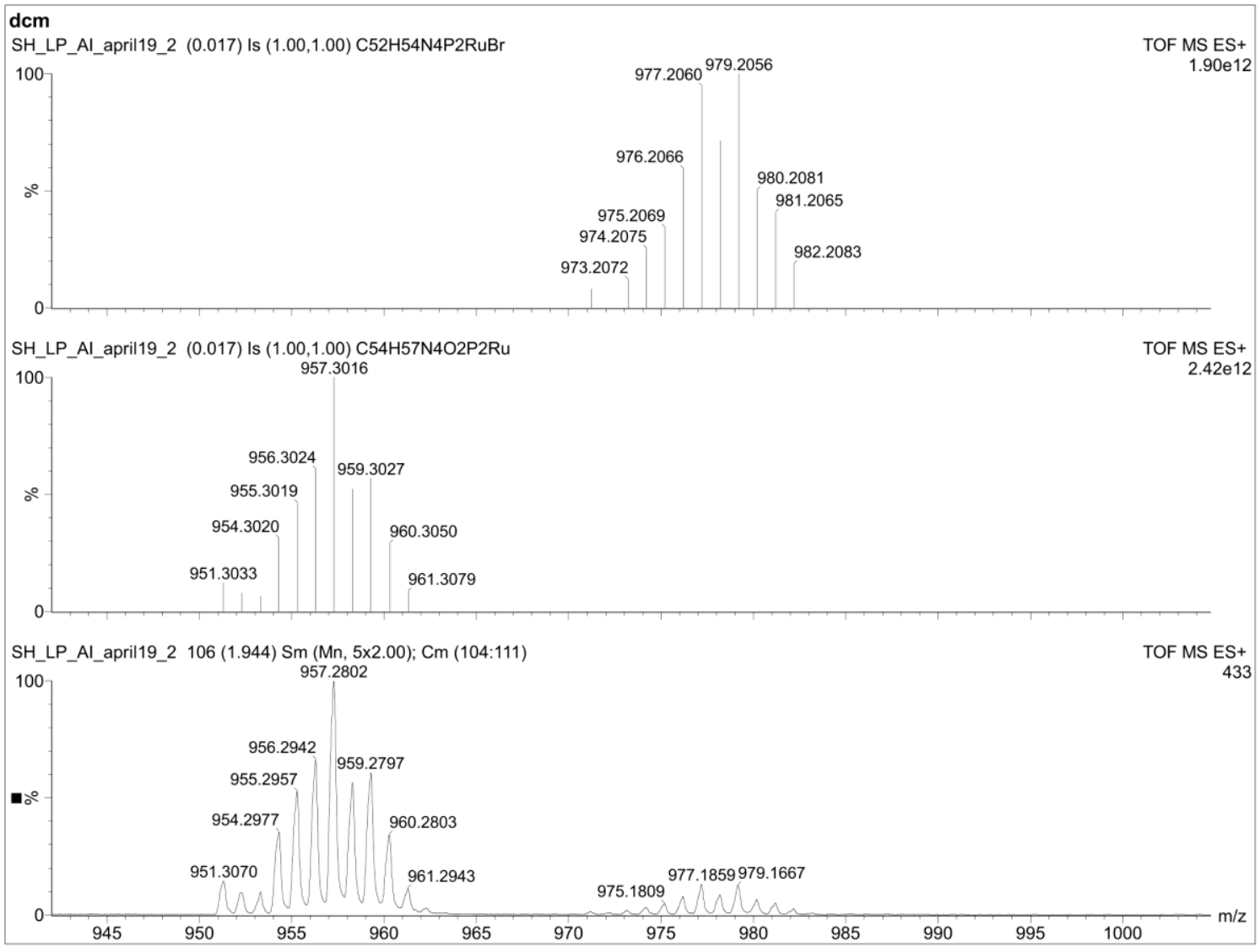

Figure S4. LIFDI-MS of complex 3.

Top: calculated [3-OAc]. Middle: calculated [3-Br-]. Bottom: measured. 


\section{Synthesis of 4.}

1) Method with $i \mathrm{PrOH} / \mathrm{NaO} i \mathrm{Pr}$

$2(50 \mathrm{mg}, 0.05 \mathrm{mmol}, 1.0 \mathrm{eq})$ are dissolved in a $0.05 \mathrm{M}$ solution of $\mathrm{NaO} i \operatorname{Pr}$ in $i \operatorname{PrOH}(5 \mathrm{~mL}, 5.0 \mathrm{eq})$ and stirred at $80^{\circ} \mathrm{C}$ for $2 \mathrm{~h}$. The solvent is removed under reduced pressure, the residue is dissolved in toluene. The resulting suspension is filtered and the solvent is removed under reduced pressure. The residue is washed with $n$-hexane $(3.5 \mathrm{~mL})$. The product $(20 \mathrm{mg})$ is not obtained purely according to the presence of decomposition products.

${ }^{1}$ H NMR (400 MHz, $\mathrm{C}_{6} \mathrm{D}_{6}$, RT, selected signals) $\delta=8.05-7.91(\mathrm{~m}, 4 \mathrm{H}), 6.86(\mathrm{~s}, 2 \mathrm{H}), 6.11$ (d, J=1.9, 2H), $5.92(\mathrm{~d}, J=1.9,2 \mathrm{H}), 2.91(\mathrm{dt}, J=21.3,5.5,4 \mathrm{H}), 2.50(\mathrm{~s}, 6 \mathrm{H}), 2.19(\mathrm{~s}, 6 \mathrm{H}), 1.72(\mathrm{~s}, 3 \mathrm{H}), 1.48(\mathrm{~s}, 6 \mathrm{H}),-6.78$ (dd, $J=87.1,19.6,2 \mathrm{H})$.

${ }^{31} \mathbf{P}\left\{{ }^{1} \mathbf{H}\right\} \mathbf{N M R}\left(162 \mathrm{MHz}, \mathrm{C}_{6} \mathrm{D}_{6}, \mathrm{RT}\right): \delta 39.0(\mathrm{~s})$.

MS (LIFDI) $m / z(\%): 900(100)[\mathrm{M}]$.

2) Method with $\mathrm{H}_{2}$ gas

$2(50.0 \mathrm{mg}, 0.05 \mathrm{mmol}, 1 \mathrm{eq})$ and $\mathrm{KOtBu}(28.0 \mathrm{mg}, 0.25 \mathrm{mmol}, 5 \mathrm{eq})$ are suspended in $15 \mathrm{~mL}$ of dry and degassed toluene in a Fisher-Porter-bottle. The reaction vessel is pressurized with 5 bar $\mathrm{H}_{2}$ and stirred at $70{ }^{\circ} \mathrm{C}$ for $2 \mathrm{~h}$. The resulting suspension is filtered, and the solvent is removed under reduced pressure. The residue is washed with $n$-hexane $(3 \cdot 5 \mathrm{~mL})$. The product $(35 \mathrm{mg})$ is not obtained purely according to the presence of decomposition products. Single crystals were obtained by cooling the first $n$-hexane washing solution to $-31^{\circ} \mathrm{C}$. 


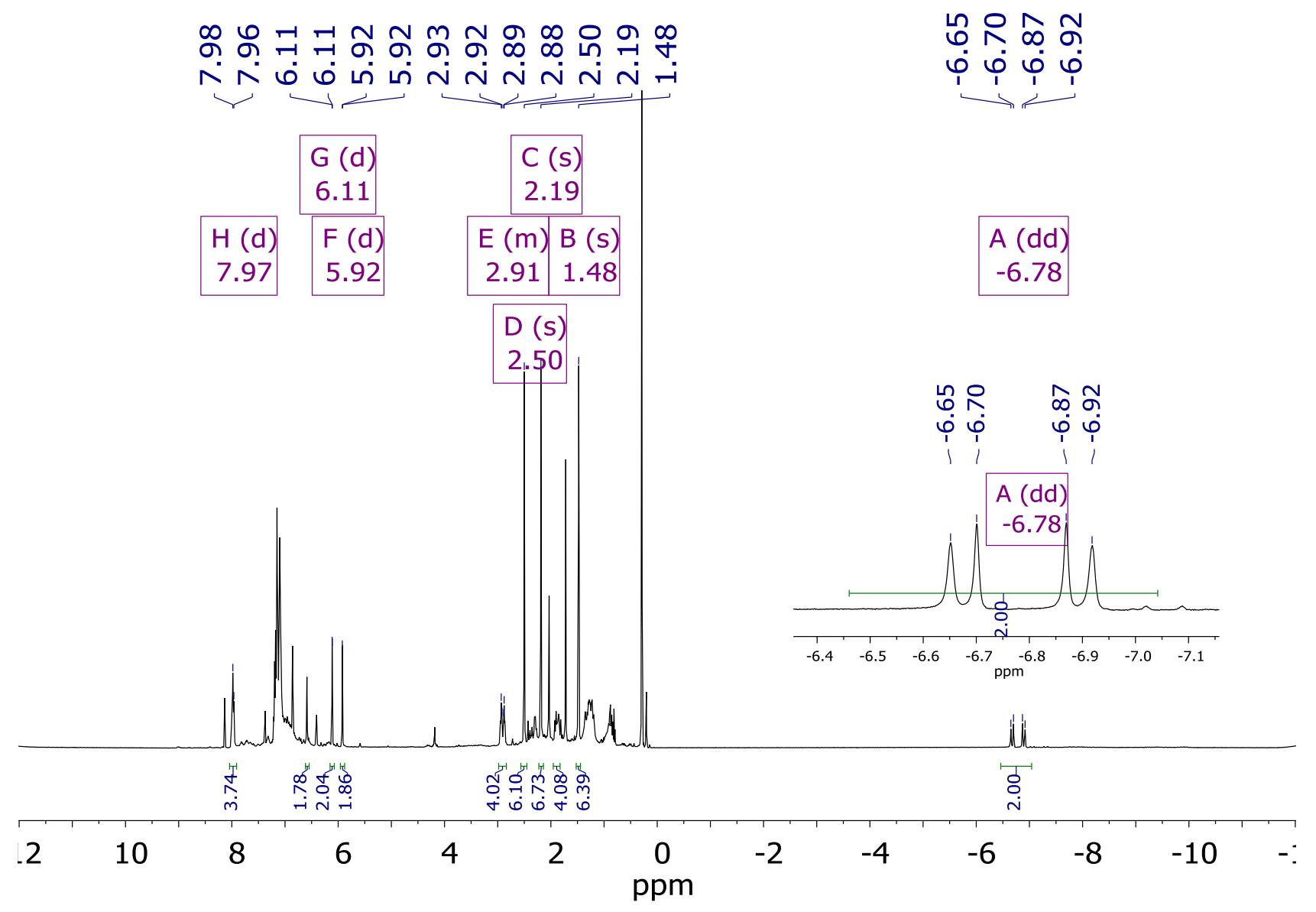

Figure S5. ${ }^{1} \mathrm{H}$ NMR $\left(400 \mathrm{MHz}, \mathrm{C}_{6} \mathrm{D}_{6}\right)$ spectrum of 4 . 


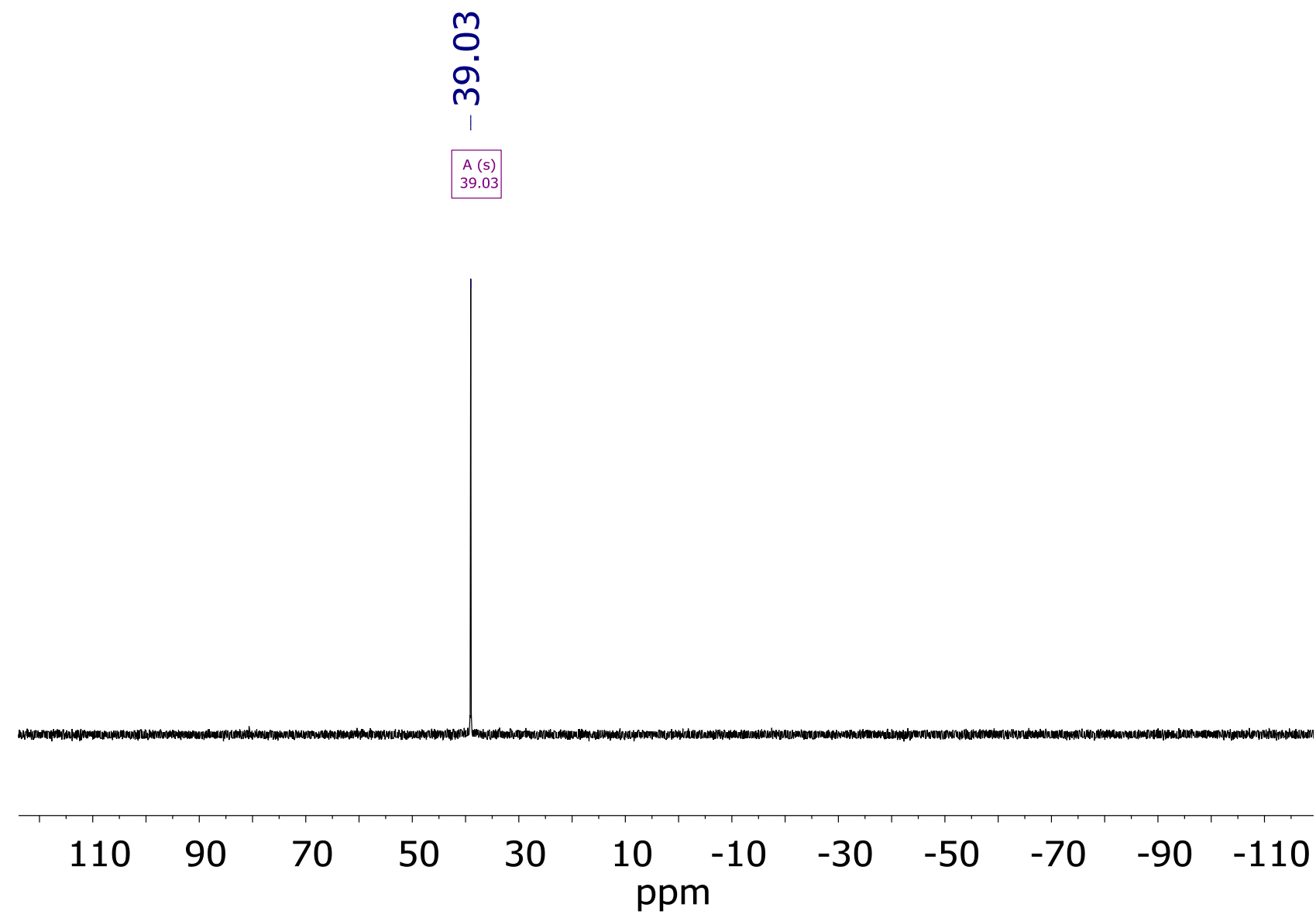

Figure S6. ${ }^{31} \mathrm{P}\left\{{ }^{1} \mathrm{H}\right\}$ NMR $\left(162 \mathrm{MHz}, \mathrm{C}_{6} \mathrm{D}_{6}\right)$ spectrum of 4 . 


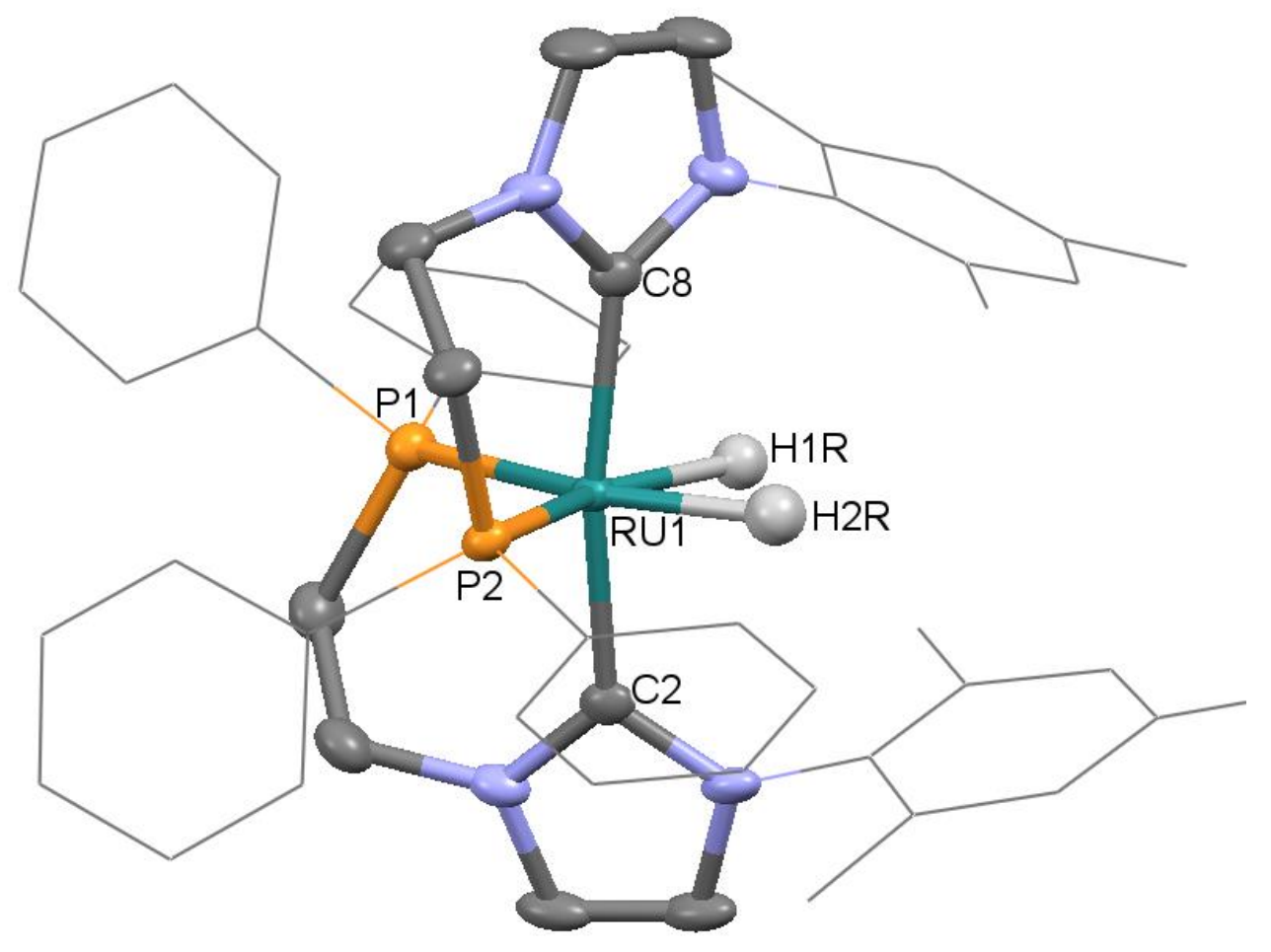

Figure S7. ORTEP-style molecular structure of 4.

Ellipsoids are shown at a 50\% probability level. Hydrogen atoms (except for the Ru-hydrides) are omitted for clarity. Only one of the independent molecules of the asymmetric unit is depicted. Grey = carbon, blue = nitrogen, yellow $=$ phosphorus, turquoise $=$ ruthenium. Selected bond lengths $(\AA)$ and angles $\left({ }^{\circ}\right):$ Ru1C2 2.075(2), Ru1-C8 2.071(2), Ru1-P1 2.2933(6), Ru1-P2 2.3015(6), Ru1-H1R 1.74(2), Ru1-H2R 1.74(3), C8-Ru1-C2 167.86(9), C2-Ru1-P1 88.15(6), C8-Ru1-P2 90.15(7), P1-Ru1-P2 108.86(2), H1RRu1-H2R 56.2(11). 


\section{${ }^{1}$ H VT-NMR study of 3 in iPrOH-d 8 .}

Complex 3 (10.0 mg, 9.64 mmol, 1 eq) is dissolved in a $10 \mathrm{M}$ solution of $\mathrm{NaO} i \operatorname{Pr}-\mathrm{d}_{7}$ in $i \mathrm{PrOH}-\mathrm{d}_{8}(1 \mathrm{~mL})$ in a sealed NMR tube. ${ }^{1} \mathrm{H}$ NMR spectra are collected consecutively at temperatures from $30^{\circ} \mathrm{C}$ to $80^{\circ} \mathrm{C}$. Thereafter, a ${ }^{1} \mathrm{H}$ NMR spectrum is collected at room temperature $\left(25^{\circ} \mathrm{C}\right)$. The deuterated solvent is removed under reduced pressure, the residue is dissolved in 2-propanol and stirred at $80^{\circ} \mathrm{C}$ for $20 \mathrm{~min}$. The solvent is removed under reduced pressure and the ${ }^{1} \mathrm{H}$ NMR spectrum of the residue is collected at room temperature $\left(25^{\circ} \mathrm{C}\right)$ in $i \mathrm{PrOH}-\mathrm{d}_{8}$.

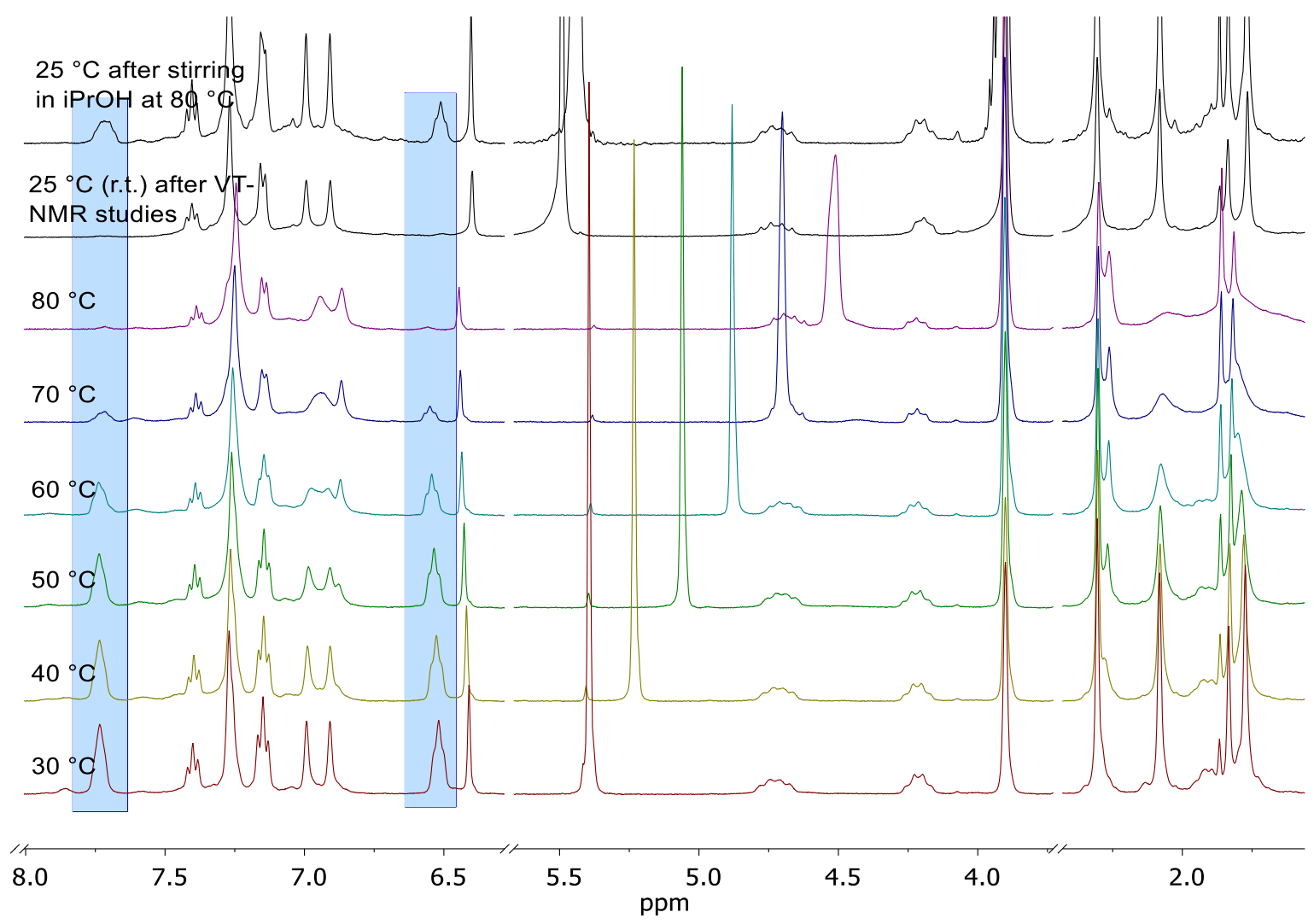

Figure S8. ${ }^{1} \mathrm{H}$ VT-NMR study of 3 in $\mathrm{iPrOH}-\mathrm{d}_{8}$ with 10 eq NaOiPr. 


\section{Catalytic Oppenauer-type Oxidation}

In a typical experiment, the reactor is charged with 3 taken from a $1 \mathrm{mg} / \mathrm{mL}$ stock solution in DCM and dried under reduced pressure. $\mathrm{KO} t \mathrm{Bu}(2 \mathrm{~mol} \%), t \mathrm{BuOH}(4.6 \mathrm{~mL})$ and the substrate $0.5 \mathrm{mmol}$ are added and the mixture is stirred and heated to the desired temperature for $1 \mathrm{~min}$. The reaction is started by addition of acetone $(200 \mu \mathrm{L}, 6 \mathrm{eq})$. At the required reaction times, aliquots of $0.3 \mathrm{~mL}$ are taken with a syringe and quenched in cooled $\left(0^{\circ} \mathrm{C}\right)$ diethyl ether. The samples are filtered over a short pad of silica and analyzed by gas chromatography. Blanc experiments without the catalyst, without acetone or without the base show no conversion of the substrates within the investigated reaction times.

\section{Neat catalytic Oppenauer-type Oxidation}

In a typical experiment, the reactor is charged $380 \mu \mathrm{L}$ of a $2 \mathrm{mg} / \mathrm{mL}$ stock solution of the $3 \mathrm{in} \mathrm{DCM}$. The solvent is removed under reduced pressure and the degassed $\alpha$-tetralol $(1.47 \mathrm{mmol})$ and $\mathrm{KO} t \mathrm{Bu}(2 \mathrm{~mol} \%$, $3.3 \mathrm{mg}$ ) are added. After stirring the mixture at $40^{\circ} \mathrm{C}$ for $1 \mathrm{~min}$., acetone $(2 \mathrm{eq}, 218 \mu \mathrm{L})$ was added as the reaction starter. Samples of $50 \mu \mathrm{L}$ were taken after at the required reaction times and quenched in ice-cold $\left(0^{\circ} \mathrm{C}\right)$ diethyl ether. The samples are filtered over a short pad of silica and analyzed by gas chromatography. Blanc experiments without the catalyst, without acetone or without the base show no conversion of the substrates within the investigated reaction times.

\section{Preparation of $a$-tetralone from $a$-tetralol}

The reactor is charged with $3.5 \mathrm{mg}(3.38 \mu \mathrm{mol}, 0.05 \mathrm{~mol} \%)$ of $3,15.4 \mathrm{mg}$ of $\mathrm{KOtBu}(2 \mathrm{~mol} \%)$ and degassed a-tetralol $(1.02 \mathrm{~g}, 6.88 \mathrm{mmol}, 0.94 \mathrm{~mL})$ and the reaction mixture is stirred at $40^{\circ} \mathrm{C}$ for $1 \mathrm{~min} .1 .02 \mathrm{~mL}$ of acetone $(0.80 \mathrm{~g}, 13.8 \mathrm{mmol}, 2 \mathrm{eq})$ are added and the mixture is allowed stirring for $5 \mathrm{~min}$. The reaction vessel is thereafter put on ice, the reaction mixture is diluted with diethyl ether and the mixture is filtered over a pad of silica $(10 \mathrm{~cm} \cdot 2 \mathrm{~cm})$. The product is obtained by evaporation of the solvent. Yield: $0.98 \mathrm{~g}$ $(98 \%)$.

\section{Catalytic Transfer Hydrogenation}

In a typical experiment, the reactor is charged with $3(0.01 \mathrm{~mol} \%)$ taken from a $1 \mathrm{mg} / \mathrm{mL}$ stock solution in DCM and dried under reduced pressure. 2-Propanol $(9.6 \mathrm{~mL})$ and the substrate $(1.0 \mathrm{mmol})$ are added and the mixture is stirred and heated to the desired temperature for $2 \mathrm{~min}$. The reaction is started by addition of 
a $0.1 \mathrm{M}$ solution of $\mathrm{NaOiPr}$ in 2-propanol $(200 \mu \mathrm{L}, 0.02 \mathrm{mmol}, 2 \mathrm{~mol} \%)$. At the required reaction times, aliquots of $0.5 \mathrm{~mL}$ are taken with a syringe and quenched in a cooled solution $\left(0^{\circ} \mathrm{C}\right)$ of diethyl ether. The samples are filtered over a short pad of silica and analyzed by gas chromatography. Blanc experiments without the catalyst or without the base show no conversion of the substrates within the investigated reaction times.

\section{TON determination in TH}

The reactor is charged with $3(0.005 \mathrm{~mol} \%)$ taken from a $1 \mathrm{mg} / \mathrm{mL}$ stock solution in 2-propanol. 2Propanol $(19 \mathrm{~mL})$ and acetophenone $(481 \mathrm{mg}, 4.0 \mathrm{mmol})$ are added and the mixture is stirred and heated to $80^{\circ} \mathrm{C}$ for $2 \mathrm{~min}$. The reaction is started by addition of a $0.1 \mathrm{M}$ solution of $\mathrm{NaOiPr}$ in 2-propanol ( $800 \mu \mathrm{L}$,

$0.08 \mathrm{mmol}, 2 \mathrm{~mol} \%)$. At the required reaction times, aliquots of $0.5 \mathrm{~mL}$ are taken with a syringe and quenched in a cooled solution $\left(0^{\circ} \mathrm{C}\right)$ of diethyl ether. The samples are filtered over a short pad of silica and analyzed by gas chromatography. Blanc experiments without the catalyst or without the base show no conversion of the substrates within the investigated reaction times. Final conversion: 90\%; TON: 18000. 


\section{Table S1.}

Catalytic Oppenauer-type oxidation of alcohols (a-i) (0.1 M) with acetone (2-6 equiv) by application of 3 $(\mathrm{S} / \mathrm{C}=1000-10000)$ as the catalyst and $\mathrm{KO} t \mathrm{Bu}(2 \mathrm{~mol} \%)$ in $t \mathrm{BuOH}(5 \mathrm{~mL})$.

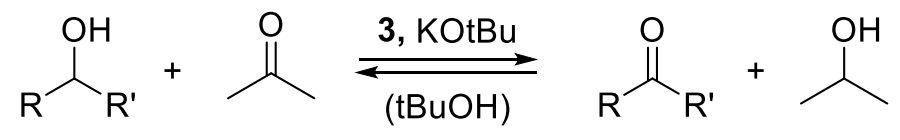<smiles>OC1CCCc2ccccc21</smiles>

a<smiles>OC1CCc2ccccc21</smiles>

b<smiles>CCCC(O)CCC</smiles>

f<smiles>OC1c2ccccc2-c2ccccc21</smiles>

c<smiles>CC(O)c1ccccc1</smiles>

d<smiles>CCCC(C)C</smiles>

\begin{tabular}{ccccccc}
\hline Entry & Substrate & $\mathrm{S} / \mathrm{C}$ & $\mathrm{T} /{ }^{\circ} \mathrm{C}$ & $\mathrm{TOF}^{b} / \mathrm{h}^{-1}$ & $\mathrm{Conv}^{a} / \%$ & Time $/ \mathrm{m}$ \\
1 & $\mathbf{a}$ & 1000 & 40 & 38000 & 99 & 5 \\
2 & $\mathbf{a}$ & 2000 & 50 & 100000 & 100 & 3 \\
3 & $\mathbf{a}$ & 2000 & 40 & 40000 & 99 & 10 \\
4 & $\mathbf{a}$ & 2000 & 50 & 100000 & 100 & 3 \\
$5^{c}$ & $\mathbf{a}$ & 2000 & 40 & 100000 & $98^{d}$ & 5 \\
$6^{c}$ & $\mathbf{a}$ & 10000 & 50 & 550000 & 98 & 2 \\
7 & $\mathbf{b}$ & 2000 & 40 & 80000 & 99 & 5 \\
8 & $\mathbf{c}$ & 2000 & 60 & 4000 & 95 & 60 \\
9 & d & 1000 & 60 & 15000 & 92 & 10 \\
10 & d & 2000 & 60 & 18000 & 78 & 30
\end{tabular}




$\begin{array}{llllccl}11 & \mathbf{e} & 2000 & 60 & 25000 & 80 & 15 \\ 12 & \mathbf{f} & 1000 & 60 & 10000 & 87 & 30 \\ 13 & \mathbf{g} & 5000 & 40 & 24000 & 97 & 20 \\ 14 & \mathbf{h} & 2000 & 40 & 2000 & 45 & 60 \\ 15 & \mathbf{h} & 2000 & 50 & 12000 & 67 & 45 \\ 16 & \mathbf{h} & 2000 & 60 & 60000 & 99 & 10 \\ 17 & \mathbf{i} & 1000 & 80 & 3400 & 90 & 60 \\ 18^{e} & \mathbf{a} & 2000 & 40 & 12000 & 99 & 20\end{array}$

\footnotetext{
${ }^{a}$ The conversion was determined by GC and NMR analysis. ${ }^{b}$ Turnover frequency (moles of alcohol converted to ketone per mole of catalyst per hour) at $50 \%$ conversion. ${ }^{c}$ reaction carried out without solvent, acetone/substrate $=2 .{ }^{\mathrm{d}}$ isolated yield after column chromatography. ${ }^{\mathrm{e}}$ with acetophenone in place of acetone.
} 


\section{Table S2.}

Catalytic TH of ketones with $3(\mathrm{~S} / \mathrm{C}=10000)$ and $\mathrm{NaOi} \operatorname{Pr}(2 \mathrm{~mol} \%)$ in 2-propanol.

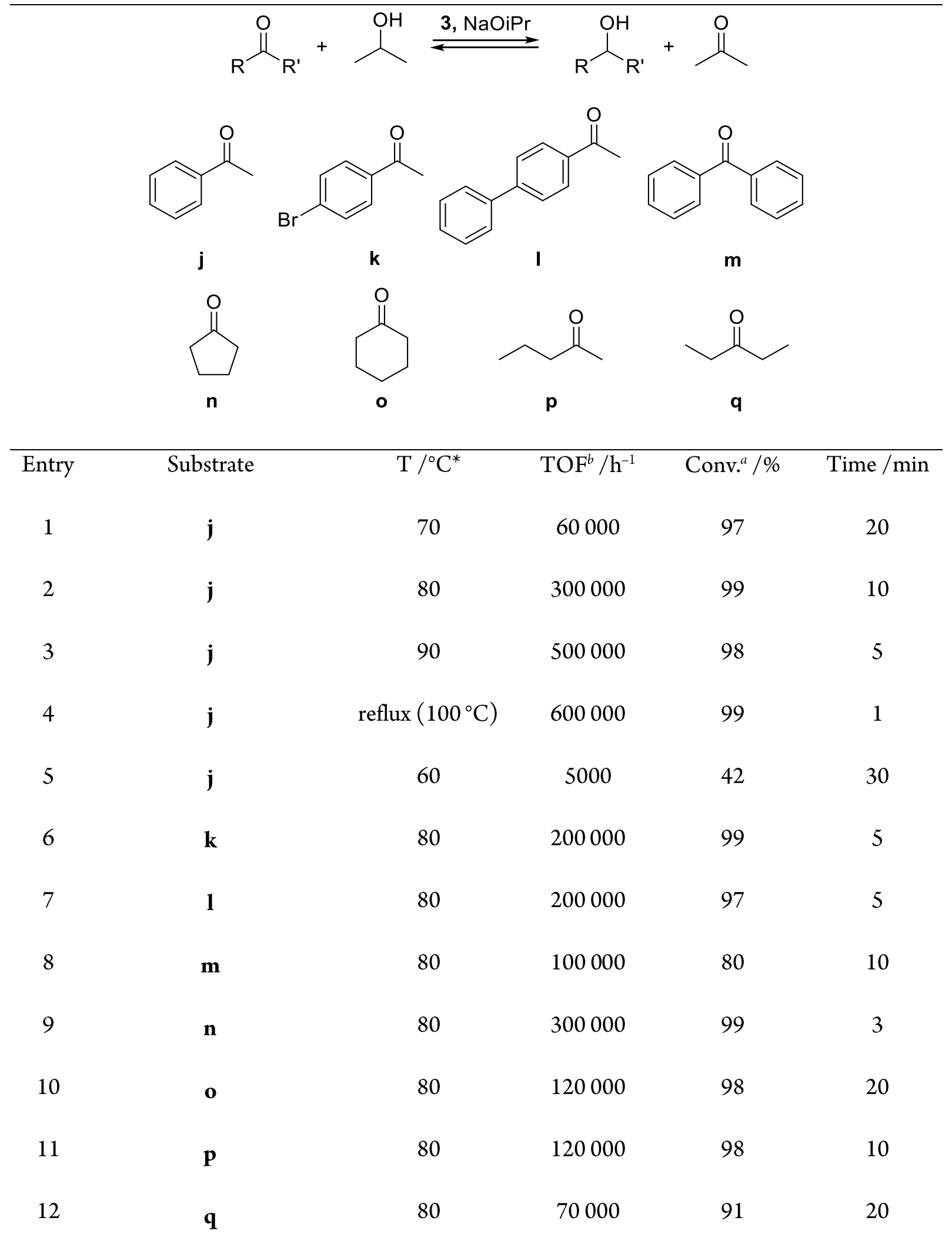

\footnotetext{
${ }^{\mathrm{a}}$ The conversion was determined by GC. ${ }^{\mathrm{b}}$ Turnover frequency (moles of ketone converted to alcohol per mole of catalyst per hour) at $50 \%$ conversion.
} 


\section{Control Experiments in TH}

To investigate the reaction kinetics in the first minutes of the $\mathrm{TH}$ of acetophenone, samples were taken every $10 \mathrm{sec}$ at $100^{\circ} \mathrm{C}$ and every $20 \mathrm{sec}$ at $80^{\circ} \mathrm{C}$ oil bath temperature, respectively. The sampling was performed with a $30 \mathrm{~cm}$ long teflon cannula with a diameter of $1 \mathrm{~mm}$ that was shortly dipped into the reaction mixture at an Ar overpressure of 0.2 mbar. To ensure an immediate stop of the reaction, the samples of about of $0.1 \mathrm{~mL}$ of were directly quenched on ice-cold diethyl-ether. The cannula was not removed from the reaction vessel, having an open system with a continuous Ar counterflow.

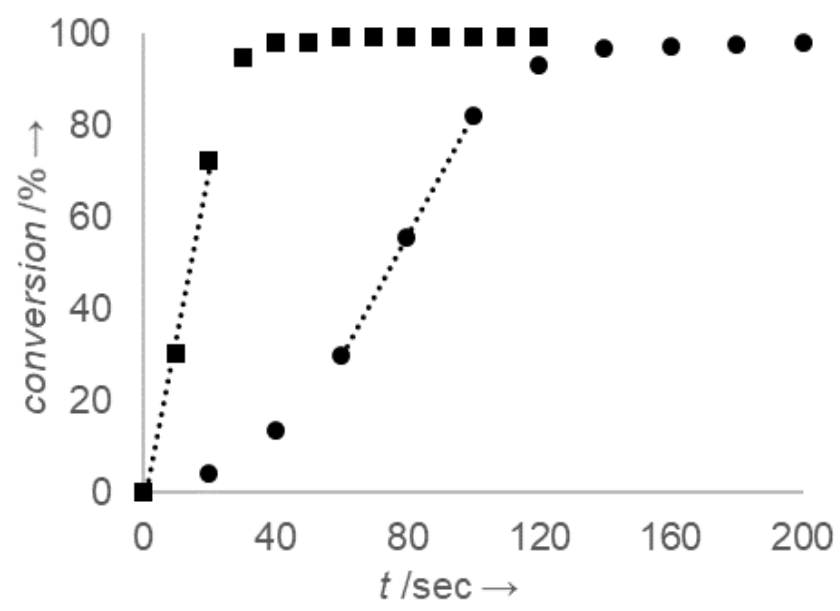

Figure S9. Course of the reduction of acetophenone catalyzed by 3. 


\section{Single crystal X-Ray structure determination. General data.}

X-ray crystallographic data were collected on different single crystal x-ray diffractometers with the following setups: ${ }^{1}$

1) a CMOS detector (Bruker APEX III, $\kappa$-CMOS), a TXS rotating anode and a Helios optic using the APEX3 software package

2) a CMOS detector (Bruker APEX III, $\kappa$-CMOS), an IMS microsource and a Helios optic using the APEX3 software package

All measurements used $\mathrm{MoK}_{\alpha}$ radiation $(\lambda=0.71073 \AA)$. The measurements were performed on single crystals coated with perfluorinated ether. The crystal was fixed on top of a kapton micro sampler and frozen under a stream of cold nitrogen. A matrix scan was used to determine the initial lattice parameters. Reflections were corrected for Lorentz and polarisation effects, scan speed, and background using SAINT. Absorption corrections, including odd and even ordered spherical harmonics were performed using SADABS. ${ }^{2}$ Space group assignments were based upon systematic absences, E statistics, and successful refinement of the structures. Structures were solved by direct methods (SHELXT) with the aid of successive difference Fourier maps, and were refined against all data using SHELXL-2014 in conjunction with SHELXLE. ${ }^{3,4}$ Hydrogen atoms were calculated in ideal positions as follows: Methyl hydrogen atoms were refined as part of rigid rotating groups, with a $\mathrm{C}-\mathrm{H}$ distance of $0.98 \AA$ and $\mathrm{U}_{\mathrm{iso}(\mathrm{H})}=1.5 \cdot \mathrm{U}_{\mathrm{eq}(\mathrm{C})}$. Other $\mathrm{H}$ atoms were placed in calculated positions and refined using a riding model, with methylene and aromatic C-H distances of $0.99 \AA$ and $0.95 \AA$, respectively, other $\mathrm{C}-\mathrm{H}$ distances of $1.00 \AA$ and $\mathrm{U}_{\text {iso }(\mathrm{H})}=1.2 \cdot \mathrm{U}_{\mathrm{eq}(\mathrm{C})}$. Positions of $\mathrm{H}$ atoms bound to ruthenium were refined freely with $\mathrm{U}_{\mathrm{iso}(\mathrm{H})}=1.5 \cdot \mathrm{U}_{\mathrm{eq}(\mathrm{Ru})}$. Non-hydrogen atoms were refined with anisotropic displacement parameters. Full-matrix least-squares refinements were carried out by minimizing $\sum \mathrm{w}\left(\mathrm{F}_{\mathrm{o}}{ }^{2}-\mathrm{F}_{\mathrm{c}}{ }^{2}\right)^{2}$ with SHELXL weighting scheme. ${ }^{3}$ Neutral atom scattering factors for all atoms and anomalous dispersion corrections for the non-hydrogen atoms were taken from International Tables for Crystallography. ${ }^{5}$ Images of the crystal structures were generated with Mercury. ${ }^{6}$ CCDC 1936771-1936772 contain the supplementary crystallographic data for this paper. These data can be obtained free of charge via www.ccdc.cam.ac.uk/data_request/cif, or by emailing data_request@ccdc.cam.ac.uk, or by contacting The Cambridge Crystallographic Data Centre, 12 Union Road, Cambridge CB2 1EZ, UK; fax: +44 1223336033. 
Single crystal X-ray structure determination. Detailed crystallographic data.

\subsubsection{Crystallographic Data of Complex 3 CCDC: 1936771}

\begin{tabular}{ll}
\hline Sample and Crystal Data & \\
\hline Chemical formula & $\mathrm{C}_{55.86} \mathrm{H}_{60.72} \mathrm{BrCl}_{4} \mathrm{~N}_{4} \mathrm{O}_{2} \mathrm{P}_{2} \mathrm{Ru}$ \\
Formula weight & $1204.83 \mathrm{~g} \mathrm{~mol}^{-1}$ \\
Temperature & $100(2) \mathrm{K}$ \\
Wavelength & $0.71073 \AA$ \\
Crystal size & $0.150 \mathrm{~mm} \times 0.207 \mathrm{~mm} \times 0.245 \mathrm{~mm}$ \\
Crystal habit & Clear yellow fragment \\
Crystal System & Monoclinic \\
Space group & $\mathrm{P} 121 / \mathrm{n} 1$ \\
Unit cell dimensions & $a=12.4759(10) \quad \AA, \quad b=19.5565(15)$ \\
& $c=23.6332(19) \AA, \quad a=90^{\circ}, \quad \beta=104.776(2)$ \\
& $\gamma=90^{\circ}$ \\
Volume & $5575.5(8) \AA^{3}$ \\
$Z$ & 4 \\
Density (calculated) & $1.435 \mathrm{~g} \mathrm{~cm}^{-3}$ \\
Absorption coefficient & $1.291 \mathrm{~mm}^{-1}$ \\
F(000) & 2468 \\
\hline
\end{tabular}

Data Collection and Structure Refinement

\begin{tabular}{ll}
\hline Diffractometer & Bruker D8 Venture Duo IMS \\
Radiation Source & IMS microsource, Mo \\
Theta range for data collection & 2.27 to $25.03^{\circ}$ \\
Index ranges & $-14 \leq \mathrm{h} \leq 14,-23 \leq \mathrm{k} \leq 23,-28 \leq 1 \leq 28$ \\
Reflections collected & 129622 \\
Independent reflections & $9848[\mathrm{R}(\mathrm{int})=0.0511]$ \\
$\begin{array}{l}\text { Coverage of independent } \\
\text { reflections }\end{array}$ & $99.9 \%$ \\
Max. and min. transmission & \\
Data / restraints / parameters & 0.8300 and 0.7430
\end{tabular}


Goodness-of-fit on $\mathrm{F}^{2}$

1.237

$\Delta / \sigma_{\max }$

Final R indices (8880 data;

$\mathrm{I}>2 \sigma(\mathrm{I}))$

Final R indices (all data)

Largest diff. max. min.
0.001

$R_{1}=0.0656, w R_{2}=0.1343$

$R_{1}=0.0710, w R_{2}=0.1363$

2.339 and $-1.069 \mathrm{e}^{-3}$ 


\subsubsection{Crystallographic Data of Complex 4 CCDC: 1936772}

\begin{tabular}{ll}
\hline Sample and Crystal Data & \\
\hline Chemical formula & $\mathrm{C}_{52} \mathrm{H}_{56} \mathrm{BrN}_{4} \mathrm{P}_{2} \mathrm{Ru}$ \\
Formula weight & $900.02 \mathrm{~g} \mathrm{~mol}^{-1}$ \\
Temperature & $100(2) \mathrm{K}$ \\
Wavelength & $0.71073 \AA$ \\
Crystal size & $0.059 \mathrm{~mm} \times 0.089 \mathrm{~mm} \times 0.170 \mathrm{~mm}$ \\
Crystal habit & Clear yellow fragment \\
Crystal System & Triclinic \\
Space group & $\mathrm{P}-1$ \\
Unit cell dimensions & $a=11.7066(4) \quad \AA, \quad b=19.2827(5)$ \\
& $c=20.5490(7) \AA$, \\
& $\beta=92.5120(10)^{\circ}, \gamma=90.7780(10)^{\circ}$ \\
Volume & $4513.6(2) \AA^{3}$ \\
Z & 4 \\
Density (calculated) & $1.324 \mathrm{gcm}^{-3}$ \\
Absorption coefficient & $0.458 \mathrm{~mm}^{-1}$ \\
F(000) & 1880 \\
\hline
\end{tabular}

Data Collection and Structure Refinement

\begin{tabular}{ll}
\hline Diffractometer & Bruker D8 Venture \\
Radiation Source & TXS rotating anode, Mo \\
Theta range for data collection & 2.08 to $25.01^{\circ}$ \\
Index ranges & $-13 \leq \mathrm{h} \leq 13,-22 \leq \mathrm{k} \leq 22,-24 \leq 1 \leq 24$ \\
Reflections collected & 185271 \\
Independent reflections & $15878[\mathrm{R}(\mathrm{int})=0.0771]$ \\
Coverage of independent & $99.8 \%$ \\
reflections & \\
Max. and min. transmission & 0.9730 and 0.9260 \\
Data / restraints / parameters & $15878 / 211 / 1172$ \\
Goodness-of-fit on $\mathrm{F}^{2}$ & 1.019
\end{tabular}


$\Delta / \sigma_{\max }$

Final R indices ( 8880 data;

$\mathrm{I}>2 \sigma(\mathrm{I}))$

Final R indices (all data)

Largest diff. max. min.
0.002

$R_{1}=0.0288, w R_{2}=0.0631$

$R_{1}=0.0433, w R_{2}=0.0680$

0.940 and $-0.457 \mathrm{e}^{-3}$ 


\section{Single crystal X-ray structure determination. References.}

(1) APEX suite of crystallographic software, APEX 3, Version 2014-9.0 and APEX 3, Version 2015-5.2, Bruker AXS Inc., Madison, Wisconsin, USA, 2015.

(2) SAINT, Versions 8.34A and 8.37A and SADABS, Versions 2014/5 and 2016/2, Bruker AXS Inc., Madison, Wisconsin, USA, 2014/2016.

(3) Sheldrick, G. M. Crystal structure refinement with SHELXL. Acta Cryst. C 2015, 71, 3-8.

(4) Hübschle, C. B.; Sheldrick, G. M.; Dittrich, B. ShelXle: a Qt graphical user interface for SHELXL. J. Appl. Cryst. $2011,44,1281-1284$.

(5) International Tables for Crystallography; A. J. Wilson, Ed.; Kluwer Academic Publishers: Dordrecht, The Nederlands, 1992; Vol. C, Tables 6.1.1.4 (pp 500-502), 4.2.6.8 (pp 219-222), and 4.2.4.2 (pp 193-199).

(6) Macrae, C. F.; Bruno, I. J.; Chisholm, J. A.; Edgington, P. R.; McCabe, P.; Pidcock, E.; RodriguezMonge, L.; Taylor, R.; van de Streek, J.; Wood, P. A. Mercury CSD 2.0- new features for the visualization and investigation of crystal structures. J. Appl. Cryst. 2008, 41, 466-470. 


\section{Buried Volume Calculations}

In order to determine the buried volume of compound 3 and 4 DFT calculations were performed using Gaussian- $16^{1}$ with the pure functional B97 ${ }^{2}$ and Grimme's D3BJ dispersion ${ }^{3}$. The double- $\zeta$ basis set def2$\mathrm{SVP}^{4}$ is applied for all atoms and $\mathrm{Ru}$ is treated by the Stuttgart-Dresden effective core potential ${ }^{5}$ as implemented in Gaussian. No symmetry or internal coordinate constraints were used during optimization. The reported geometries are true ground states verified by the absence of negative eigenvalues in the vibrational frequency calculations. The para-methyl groups of the Mes moieties are removed to facilitate convergence. The buried volume is calculated by the SambVca tool ${ }^{6}$ using scaled Van-der-Waals radii (1.17) and a sphere radius of 3.5 and $5 \AA$ respectively. Hydrogens are neglected and the acetate in compound $\mathbf{3}$ and the hydrides in $\mathbf{4}$ are removed. 


\section{Table S3.}

Buried volumes of compounds 3 and $\mathbf{4}$ for sphere radii of $3.5 \AA$ and $5.0 \AA$, respectively. The applied internal coordinates for the calculation are given. The steric maps clearly demonstrate the steric shielding of the ruthenium center of compound $\mathbf{4}$ for both sphere radii. In contrast, compound $\mathbf{3}$ is significantly more accessible, best shown by the steric map using a sphere radius of $5 \AA$.
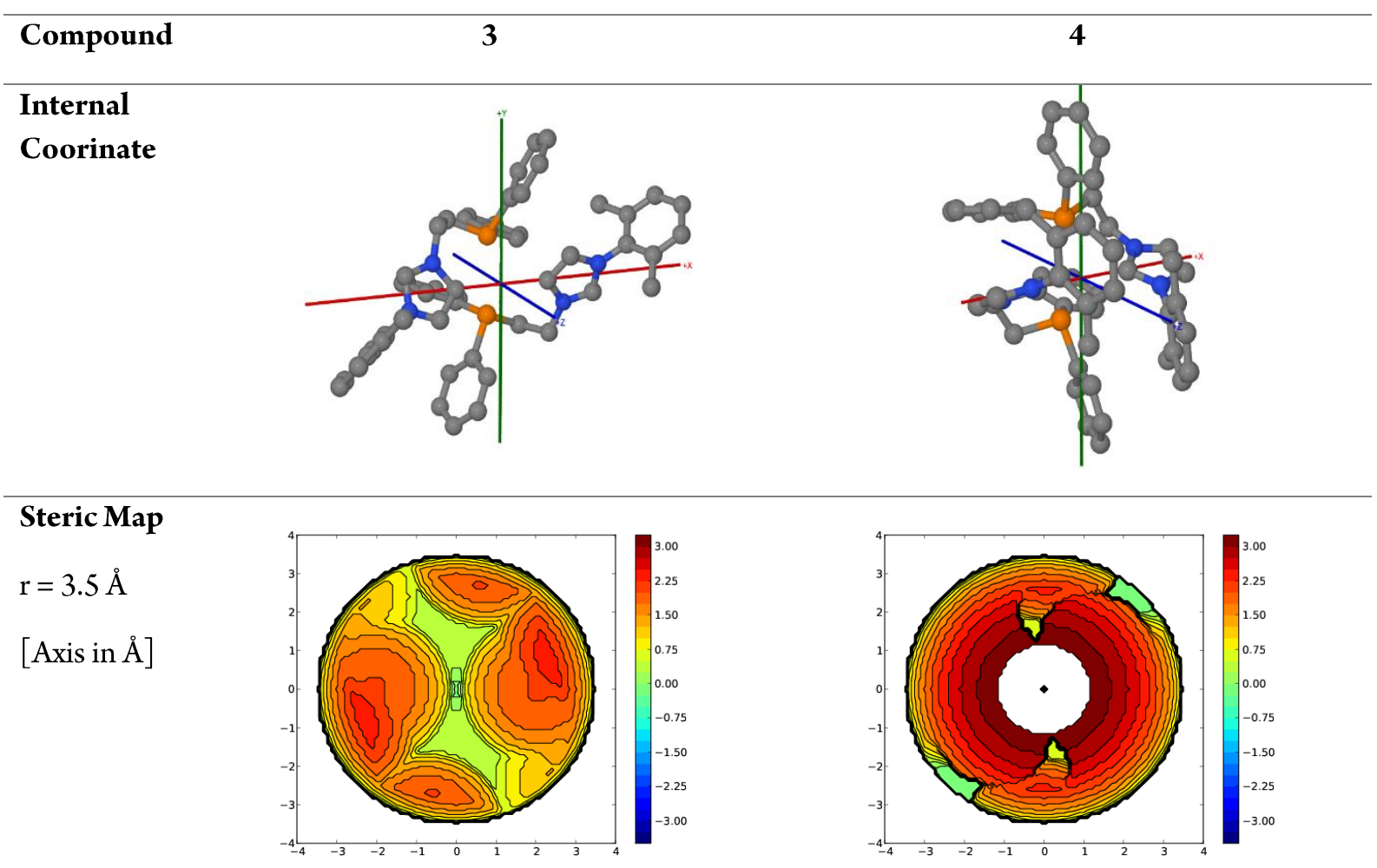

\section{Buried}

Volume

79.9

90.8

[\%]
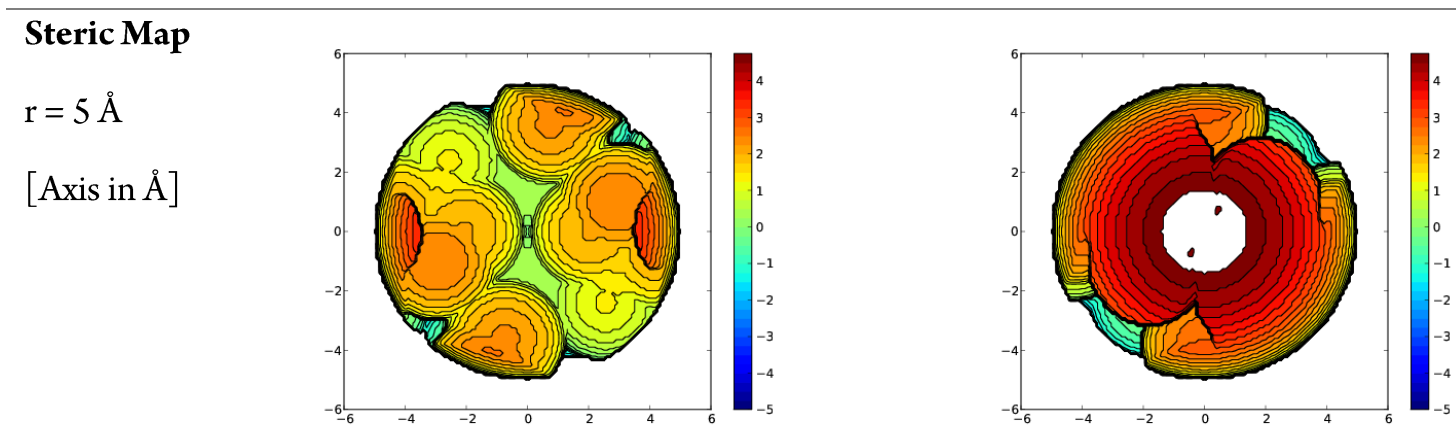

\section{Buried}

Volume

70.6

88.6

[\%] 


\section{Buried Volume Calculation References}

(1) Frisch, M.J.; Trucks, G. W.; Schlegel, H. B.; Scuseria, G. E.; Robb, M. A.; Cheeseman, J. R.; Scalmani, G.; Barone, V.; Petersson, G. A.; Nakatsuji, H.; Li, X.; Caricato, M.; Marenich, A. V.; Bloino, J.; Janesko, B. G.; Gomperts, R.; Mennucci, B.; Hratchian, H. P.; Ortiz, J. V.; Izmaylov, A. F.; Sonnenberg, J. L.; Williams-Young, D.; Ding, F.; Lipparini, F.; Egidi, F.; Goings, J.; Peng, B.; Petrone, A.; Henderson, T.; Ranasinghe, D.; Zakrzewski, V. G.; Gao, J.; Rega, N.; Zheng, G.; Liang, W.; Hada, M.; Ehara, M.; Toyota, K.; Fukuda, R.; Hasegawa, J.; Ishida, M.; Nakajima, T.; Honda, Y.; Kitao, O.; Nakai, H.; Vreven, T.; Throssell, K.; Montgomery Jr., J. A.; Peralta, J. E.; Ogliaro, F.; Bearpark, M. J.; Heyd, J. J.; Brothers, E. N.; Kudin, K. N.; Staroverov, V. N.; Keith, T. A.; Kobayashi, R.; Normand, J.; Raghavachari, K.; Rendell, A. P.; Burant, J. C.; Iyengar, S. S.; Tomasi, J.; Cossi, M.; Millam, J. M.; Klene, M.; Adamo, C.; Cammi, R.; Ochterski, J. W.; Martin, R. L.; Morokuma, K.; Farkas, O.; Foresman, J. B.; Fox, D. J. Gaussian Inc., Wallingford CT, 2016.

(2) Grimme, S. Semiempirical GGA-type density functional constructed with a long-range dispersion correction. Journal of Computational Chemistry 2006, 27, 1787-1799.

(3) Grimme, S.; Ehrlich, S.; Goerigk, L. Effect of the damping function in dispersion corrected density functional theory. Journal of Computational Chemistry 201 1, 32, 1456-1465.

(4) Schäfer, A.; Horn, H.; Ahlrichs, R. Fully optimized contracted Gaussian basis sets for atoms Li to Kr. The Journal of Chemical Physics 1992, 97, 2571-2577.

(5) Bergner, A.; Dolg, M.; Küchle, W.; Stoll, H.; Preuß, H. Ab initio energy-adjusted pseudopotentials for elements of groups 13-17. Molecular Physics 1993, 80, 1431-1441.

(6) Falivene, L.; Credendino, R.; Poater, A.; Petta, A.; Serra, L.; Oliva, R.; Scarano, V.; Cavallo, L. Organometallics 2016, 35, 2286-2293. 